\title{
Community's Perception of a Protected Area on the Impact of Tourism: The Santay Island Case of Ecuador
}

\author{
Mauricio Carvache-Franco
}

Universidad Espíritu Santo-Ecuador

Wilmer Carvache-Franco

Escuela Superior Politécnica del Litoral, ESPOL, Facultad de Ciencias Sociales y Humanísticas,

Guayaquil, Ecuador

\section{Diana Cecilia Sánchez-Riera}

Universidad de Chile, Santiago, Metropolitan Region, Chile

\section{Orly Carvache-Franco}

Universidad Católica Santiago de Guayaquil, Facultad de Especialidades Empresariales

Doi: 10.2478/mjss-2018-0112

\section{Abstract}

Carrying out studies on the impact of the development of tourism in a community allows to have information about the positive or negative perception in the economic, sociocultural and environmental aspects that are part of their environment. The present empirical research was developed in situ on the Santay Island Ramsar site and protected area located in Guayaquil, Ecuador. Using a questionnaire, the perception of the Community in the face of tourism development was analysed, evidencing that the positive aspects most valued by the commune were "The inhabitants of the island feel more pride for belonging to it" (sociocultural aspect), "Improvement of access roads to the Island" (environmental aspect), "Improvement of quality of life "(sociocultural aspect)," Improves the quality of service in restaurants, shops and cabins in the area "(sociocultural aspect) and" Contribution to improve the standard of living "(economic aspect). The benefits derived from tourism development (positive aspects) outnumber and score the costs (negative aspects), so the community is in favour of tourism development. The general satisfaction of the commune with the tourism development in Isla Santay is considered a high. The variables that show a significant and positive correlation in community satisfaction with tourism development are the "Improvement of investments, more development and more infrastructure".

Keywords: Development, Community, Protected Area, Ramsar, Tourism, Santay

\section{Introduction}

Local community is a fundamental part for a destination's tourism development, for which it is very important to carry out research involving their perception of this important sector of the economy of any given country. In this field, the local development of tourism brings with it both positive and negative effects, which causes a growing interest of studying this subject (Ko \& Stewart, 2002; Lankford \& Howard, 1994). About this matter, Brida, Osti, and Barquet (2010), argue that residents 
are the ones who are exposed to the numerous effects of tourism development. Meanwhile, Easterling (2005) states that the majority of residents tend to realize that tourism has positive and negative consequences. From a positive perspective, communities receive an increase in resident' quality life, strengthening business networks, as well as collaboration in order to promote and preserve archaeological sites and monuments, which are beneficial aspects that a community receives for the benefit of tourism. (Akis, Peristianis, \& Warne, 1996; Yoon, Gursoy, \& Chen, 200; Andereck, Valentine, Knopf, \& Vogt, 2005; Oviedo-Garcia, Castellanos-Verdugo \& Martin-Ruiz, 2008).

On the one hand, according to Gursoy, Chi and Dyer (2009), most studies establish that the economic impact is generally seen as positive on the development of a tourist destination; likewise, Choi, \& Sirakaya (2005) mention employment and other economic opportunities for the residents. However, it is believed that only a small percentage of the resident population receives these benefits (Sreekumar \& Parayil, 2002).

On the other hand, tourism has negative aspects, such as environmental damage, with significant increases in waste and pollution. (Brunt \& Courtney, 1999; McGehee \& Andereck, 2004; Snaith \& Haley, 1999; Andereck et al., 2005). Another negative impact is the one that occurs in peak seasons where public sites and leisure facilities become saturated, and sometimes traffic becomes congested and parking problems increase (Lindberg \& Johnson, 1997; Sheldon \& Abenoja, 2001). Thus, the impacts on residents go beyond the economic effects, according to Santana (1997) and Anderek et al. (2005) tourism development also causes social, cultural and environmental impacts.

In this context, Santay and Gallo Islands were declared a National Recreation Area with 2,214 hectares, joining the Patrimony of the State's Natural Areas, this decree was signed in February, 2010 and among its benefits an ecological destination visited by tourists was brought to the city of Guayaquil. On this Island takes place an association of residents called "San Jacinto of Santay" that carry out the following activities: fishing, tourism and up to nowadays they provide community based tourism. Among the main tourist activities that are carried out on the island, there are for instance, bike riding, flora and fauna sightseeing, hiking, gastronomy, among others. As for the number of tourists in the recreation area, based on the information received by the Ministry of Environment of 2017, in the year 2015 Santay and the Gallo received 491,417 visitors and in year 2016 they received 349,688 national visitors and 10,680 foreign visitors, adding up to 360,368 tourists.

Recent studies (Diaz-Christiansen, López-Guzmán, \& Pérez-Gálvez, 2016) establish that tourists visiting Santay Island have their motivations in leisure, family, friends and health (Minciu, 2004) and motivational factors such as intellectual, social, challenge and relaxation (Mahika, 2011). Other current research (Diaz-Christiansen, López-Guzmán, Péres, \& Muñoz 2016) determines that the designation of Santay Island as a Ramsar Site, confers this place a positive privilege in order to continue its improvement and development as a natural destination in Ecuador. In this sense, it is necessary to continue working for the sustainable development of the tourist destination managed from the local community of San Jacinto of Santay.

So far, no empirical study regarding the analysis of the perception of the community of Santay Island in relation to the tourist development has been published, therefore the objective of the present study is to present an analysis of the perception of the community in regard of the tourism development of this Island as part of a national protected area. In order to reach this objective after the introduction, in the second section there is presented a literature review; in the third section is presented a description of the geographical area under study. The fourth segment defines the methodology and the fifth section describes the results of the research and its discussion. Finally the article shows the conclusions of the research and the bibliographical references used.

\section{Literature Review}

In Ecuador, as well as in other countries of the region, there is an attempt to identify tourism products, frequently linked to the emergence of a series of initiatives for non-conventional modalities (Schaerer \& Dirven, 2001), moreover one of the products that could be boosted in this country is community tourism. In Ecuador, several communities are benefited by the Regulation for the Registration of Community Tourist Centers (2006), which specifies that this institution 
establishes a framework within the community organization and promotes a fair, equitable, responsible and sustainable local development; based on the revaluation of its identity, customs, traditions; through an exchange of experiences involving tourists and visitors, with the goal of offering quality services and improving the living conditions of the communities.

In this context, several authors such as (Sampaio, 2005; Henríquez, Zechner, \& Sampaio, 2010) have concluded that tourism has a favorable impact on the household economics of the communities involved in this activity, especially those with socio-economic disadvantages. In this sense, over recent decades, the number of studies that consider tourism from the perspective of the resident has considerably increased (Harril, 2004; Sánchez, Bueno \& Mejía, 2007; Monterrubio, 2008). In fact, studies have been carried out on the impact of tourism in communities, such as those by (Canalejo, Soto, \& López-Guzmán, 2012; Sinclair-Maragh, Gursoy, \& Vieregge, 2015; Almeida-García, Peláez-Fernández, Balbuena-Vázquez, \& Cortés-Macias, 2016; Petric \& Pivcevic, 2016) which demonstrates the importance of the current investigation.

Due to the context mentioned in the lines above, at the 2012's Earth Summit held in Rio de Janeiro, it is settled to ensure a political commitment along with a sustainable development, as well as to evaluate the progress of its implementation and assess new emerging challenges for a sustainable development. In this field (Castillo, Gutiérrez, \& Gaspar, 2002; Infante, Aguilera, \& González, 2010) argue that the authorities should run the sustainable management of the area. Hence, in order to accomplish this, the local community should be the main character of its own development, by promoting local empowerment and citizen participation. Likewise for Cardoso (2014), sustainable tourism is not a product, but rather a required philosophical basis in order to provide directions to develop tourism among the destinations and to make good use of natural and cultural resources that inhabit it.

From this perspective, community tourism study is important, to which a large amount of research obtains as a result that in general, the touristic receptor community is influenced by the perceived impact of tourism along three basic categories of benefits and costs: economical, environmental and social (Murphy, 1985; Gunn, 1988; Gee,. Mackens \& Choy, 1989; Mclntosh \& Goeldner, 1990; Gursoy et al., 2002). Some authors desglosan the social category in two sections: social and cultural, having considered, four factor categories in total (Andereck et al., 2005). However, touristic development model and its resulting impacts are evident for members within the community and by the end of the day, the residents of the community are the ones who will reap or will either be suffocated by themselves (Petric \& Pivcevic, 2016). In this sense, Núñez, Fuentes and Sánchez (2015), against any coherent planning of touristic development of a geographic area is indispensable to consider the diverse groups of interest and specially the local community, as well as their perceptions and attitudes in regard of the impact of touristic development from an economic, social, cultural and environmental point of view. In relation to this subject, Díaz and Martínez (2002), the resident's attitude changes depending on the evolution of touristic development.

The World Tourism Organization (2004), on its guide for local managers, reveals a series of impacts both positive and negative at a socio-economic level. (Table 1)

Table 1. Socio-economic impacts of Tourism

\begin{tabular}{ll}
\hline Positive Effects & Negative Effects \\
\hline $\begin{array}{l}\text { Employment and Income of work from } \\
\text { touristic sector }\end{array}$ & Rise of the Price of lands and goods \\
$\begin{array}{l}\text { Promotion of local entrepreneurs } \\
\text { Income of currencies at National level }\end{array}$ & $\begin{array}{l}\text { Loss of authenticity among cultural manifestations. } \\
\text { Social problems, such as, alcoholism, prostitution and drugs, } \\
\text { etcetera. }\end{array}$ \\
$\begin{array}{ll}\text { Multiplying effect of tourism in other economic } \\
\text { activities. }\end{array}$ & $\begin{array}{l}\text { Demonstration effect (Imitation of ways of dressing and acting } \\
\text { from tourists). }\end{array}$ \\
$\begin{array}{l}\text { Improvement of financial infrastructure. } \\
\text { Conservation of cultural patrimonies. }\end{array}$ & $\begin{array}{l}\text { Congestion of tourists in touristic locations. } \\
\text { Cultural exchange among tourists and }\end{array}$ \\
residents. & Economic benefits only for owners. \\
\hline
\end{tabular}

Source: World Tourism Organization 2004. 
In this way, tourism also offers opportunities for residents in order to meet interesting partners, consolidate friendships, learn about the world, and expose themselves towards new perspectives (Kumar, Devadas, \& Najjamuddinc, 2003). Hence, Nzama (2008) sustains that a positive relation is available between the community's scope in regard of tourism development and its perspectives towards a rise of tourism development. In this matter, Tovar and Lockwood (2008) argument that tourism rises recreational locations availability and those for entertainment among hosting communities.

On the negative side, communities are directly affected by tourism industries development and by the subsequent interactions with tourists (Sharpley, 2014). This forces may result on value changes for the community, behavior patrons, lifestyle and the quality of life for the members of a community (Hall \& Page, 2014). Consequently, they can cause tax augmentation on properties (Látková \& Vogt, 2012). In this line, by identifying attitudes of local populations, programs can be established in order to minimize friction among tourists and residents (Zhang, Inbakaran, \& Jackson, 2006).

In the same order of ideas, for Pavlić, Portolan and Puh (2015) those residents who have a better quality of life are more willing to promote tourism development. Local authorities should try to increase positive impacts of tourism and residents' perceptions of those impacts. Moreover, they should make an effort on mitigate the negative impacts associated to tourism development. On a study carried out by Eshliki and Kaboudi (2012) it is concluded that results related to the coefficients correlation indicate that there is a significant relationship between tourism effects of the community and its degree of collaboration.

In this perspective, Assante, Wen and Lottig (2012) assessed on the impact of the resident's attitudes in regard of sustainable tourism development, by indicating that the residents were aware of the positive economic impact of tourism but they were also conscious on the fact that these benefits could have a negative impact on the environment which may reduce the satisfaction with future tourism development. Although, few studies have been found about the ways in which tourism improves the general satisfaction degree of communities (Andereck \& Nyaupane, 2011).

Rasoolimanesh, Ringle, Jaafar, and Ramayah (2017) consider that local authorities should aim to increase participation from local residents on tourism development and also in within decision making processes for conservation with the goal to increase support from residents. These findings also suggest that developers and marketers of tourism must know how the residents perceive the impacts of tourism and who these affect their degree of life satisfaction, in accordance to the stages of tourism development (Kim, Uysal, \& Sirgy, 2013). At the same time, community planners have criticized tourism workers on failures at establishing a clear framework, in order to determine the factors that should be considered in decision-making (De Kadt, 1979; Gunn \& Var, 2002).

It is important to determine if the community has a positive or negative perception about the development of tourism in a certain destination, for them the study raises the following hypothesis.

$\mathrm{H}_{1}$ : The community perceives that tourism is positive for development.

$\mathrm{H}_{2}$ : The community perceives that development reaches a part of the population.

$\mathrm{H}_{3}$ : The community perceives that development is economic.

\section{Description of the Geographical Area}

Tourism sector in Ecuador occupies the third place on non-petroleum exports, after banana exports which occupies the first place and shrimp along with the second one. Based on data given by Ministry of Tourism of Ecuador MINTUR (2018). foreign currency income on travel and passenger transportation reached the sum of $1,204.5$ million dollars during the year 2017 , observing an increase of $12 \%$ relate to the previous year. According to MINTUR statistics (2018) by year 2017, $1,617,914$ international tourists arrived to Ecuador, while on year 2016, 1,412,718 international tourists arrived, which represents a growth of $14 \%$ related to the previous year.

Guayaquil city has natural and cultural attractions such as Malecon 2000, Santay Island, Historical Park, Las Peñas Sector, Santa Ana Port, Churches and Museums. This study takes place about Santay Island which is situated on Eloy Alfaro town (Durán), which is located 800 meters far 
from Guayaquil, placed on the east side, thus a bridge facilitates the access among the Island and the city. It is frequently used to walk by or as a bicycle route for inhabitants and tourists. It is also possible to cross by boat from Guayaquil to Santay Island. From Durán there is a bridge that can be walked by in a bicycle. (Figure 1)

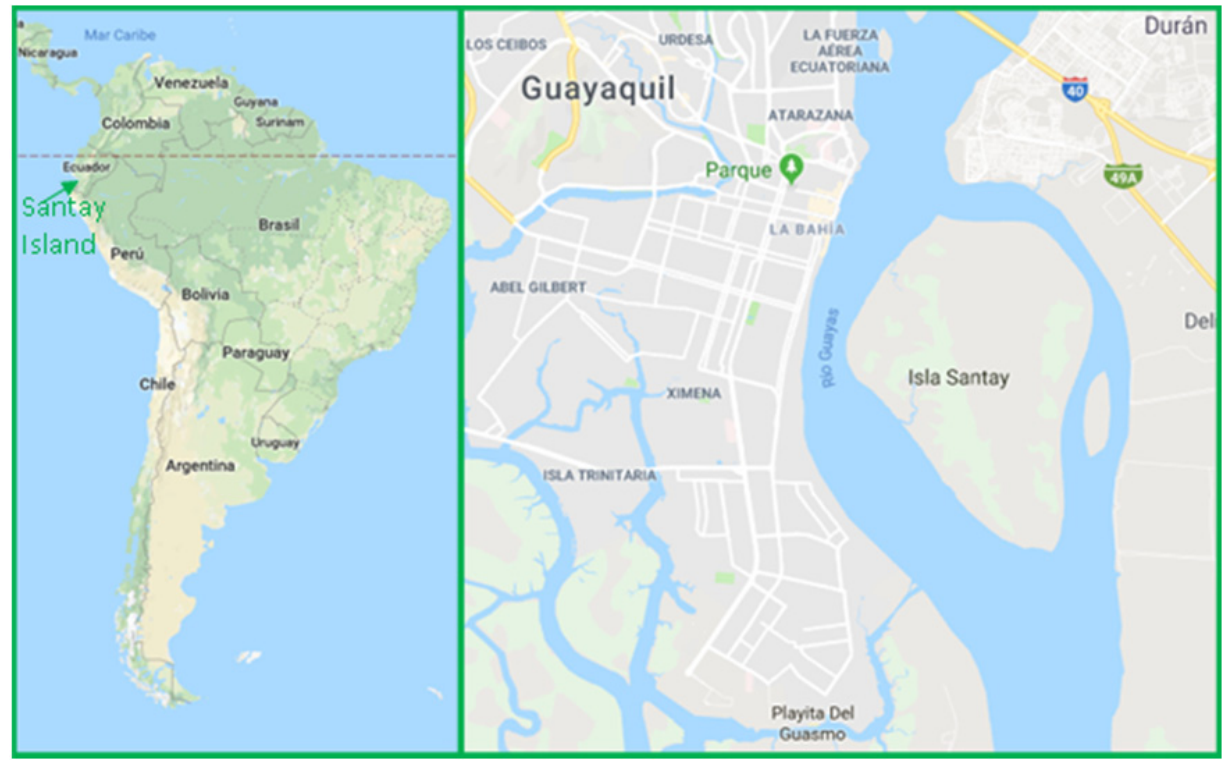

Figure 1. Geographical location of Santay Island (Ecuador)

Source: https://www.google.ec/maps/

As far as Santay Island, it has a 2,179 hectares area where an Eco-Village is situated, this EcoVillage houses 68 families, who inhabit 56 houses. Its population is distributed as show in table 1, based on data facilitated by the Ministry of Environment (2017). (Table 2)

Table 2. Number of Santay's inhabitants

\begin{tabular}{cc}
\hline Stage & Quantity \\
\hline Seniors & 13 \\
Adults & 138 \\
Adolescents & 35 \\
Under age & 77 \\
\hline Total & $\mathbf{2 6 3}$ \\
\hline
\end{tabular}

Source: Own elaboration adapted from Ministry of Environment (2017)

From a point of view of its origins, Santay Island and Gallo Island are a product of the sediments of Daule and Babahoyo River. Santay Island is covered by mangrove with 107 bird species registered. Also, there are trees such as, the Guaganaderas chapel, Cascol, Palo Prieto, Porotillo and Fernán Sanchez.

During the 40's decades, Santay Island was well known by its rice and rancher production (Municipal Public Company of Tourism, Civic Promotion and International Relations of Guayaquil, 2015). In addition, Santay Island is internationally recognized as a Ramsar site since October the $10^{\text {th }}$ of 2000 , for being the sixth declared wetland in Ecuador. This, the Eco-Village that houses the Community of San Jacinto de Santay counts on photovoltaic energy, by taking advantage of solar 
energy trough the solar panels, by charging the batteries during the day, and then at night this accumulated energy is used. The multipurpose dock is built with a mechanism that allows its adaptation with the fluctuating tide (Urban Parks and Spaces Public Company, 2014). The island has the following zones: Conservation, Tourism and Recreation, Restoration, Multiple uses and Strict conservation subzone.

\section{Methodology}

The present study is based in an empirical field research using as main tool a questionnaire based on different previous studies about perception of the communities against tourism development (Canalejo et al., 2012; Sinclair-Maragh et al., 2015; Almeida-García et al., 2016).

The field work was carried out in November 2016 in Santay Island where families inhabiting the Eco-Village from San Jacinto Community were visited. The questionnaire consisted on 14 questions, technically organized in three sections. In the first section, it was required the sociodemographic information of the community, the second section focused in the positive aspects and finally in the third section analyzed the negatives aspects of the perception against tourism development. The questionnaire was applied in Spanish, the population object of this study was the community of San Jacinto de Santay constituted by 138 inhabitants over 18 years old.

The members of the community were tested in their homes, for which they answer to the questions independently and at the same time the pollsters were eager to clarify any doubt from the respondents. The pollsters group were students form the Tourism Career of University ESPOL of Guayaquil (Ecuador), properly trained, by the authors of the present study, for this field work. A pilot test consisting on ten surveys was taken in order to validate the questionnaires. A mix of question techniques was used to obtain the most proximate results. Hence, closed-questions were used, multiple choice questions, and a set of questions with a 5 point Likert scale in order to value the opinion of the respondents.

A total of 100 surveys were applied, 87 of which were validated, being this the sample size, for which a finite population was used, with a margin of error of $+/-6.41 \%$, a confidence interval of $95 \%$ and a variance of $50 \%$. (Table 3 )

Table 3. Sample design

\begin{tabular}{ll}
\hline Population & San Jacinto de Santay Community (Guayaquil, Ecuador) \\
Geographic Area & Santay Island \\
Time period & November 2016 \\
Procedure & Simple random sampling \\
Confidence interval & $95 \%$ \\
Margin of error & $+/-6.41 \%$ \\
Validated questionnaires & 87 \\
\hline
\end{tabular}

Source: Own elaboration.

For the present study, data gathered was organized, tabulated and analyzed using SPSS software version 22. The treatment of the data was done through the use of univariate and bivariate

\section{Results and Discussion}

As shown in table 4, the sample surveyed in situ at the Commune of Santay was integrated by $50.6 \%$ men and $49.4 \%$ women. In terms of marital status, the majority group was composed of married / common-law marriage with $66.7 \%$, followed by single ones with $25.3 \%$. In terms of age, the major group consisted of ages between 18-29 years (33.3\%) followed by a second group between 30 and 44 years (25.35\%). Regarding their level of education, $59.8 \%$ had primary education, followed by $21.8 \%$ with secondary education and $13.8 \%$ without any studies.

A relation was found between sex and age (Pearson Chi-square coefficient $=10,933, p=$ 
0.027 ), between age and marital status (Pearson Chi-square coefficient $=44,246, p=0.000$ ) and between age and level of education (Pearson Chi-square coefficient $=63,218, p=0.000$ ).

Table 4. Socio-demographic aspects of the Commune of Santay

\begin{tabular}{llcllc}
\hline \multirow{2}{*}{ Variable } & \multicolumn{3}{c}{ Percentage } & Variable & \multicolumn{2}{c}{ Percentage } \\
\hline Sex & Man & $50.6 \%$ & Age & Under 18 years old & $3.4 \%$ \\
$\mathrm{~N}=87$ & Woman & $49.4 \%$ & $\mathrm{~N}=87$ & $18-29$ years old & $33.3 \%$ \\
\hline Origin & Santay Island & $60.9 \%$ & & $30-44$ years old & $25.3 \%$ \\
$\mathrm{~N}=87$ & Guayaquil & $33.3 \%$ & & $45-64$ years old & $27.6 \%$ \\
& Duran & $1.1 \%$ & & 65 and up & $10.3 \%$ \\
& Others & $4.6 \%$ & & & \\
\hline Marital status & Single & $25.3 \%$ & Education & Without studies & $13.8 \%$ \\
$\mathrm{~N}=87$ & Married/Common-law marriage & $66.7 \%$ & $\mathrm{~N}=87$ & Primary & $59.8 \%$ \\
& Widow & $5.7 \%$ & & High school & $21.8 \%$ \\
& Divorced & $2.3 \%$ & & University & $4.6 \%$ \\
\hline
\end{tabular}

Source: Own elaboration.

As part of the study it was important to determine the place of origin of the sample surveyed, for which $60.9 \%$ were original from Santay Island, followed by a $33.3 \%$ who were born in Guayaquil. Regarding how long the communards were living in Santay Island, $82.8 \%$ had been living in this destination for more than 18 years, followed by $13.8 \%$ who had been living there between 11 and 20 years. Regarding their economic activity, $20.7 \%$ were engaged in housework, followed by $37.9 \%$ who were community employees, $77 \%$ had incomes under 200 dollars, followed by $18.4 \%$ with an income between 200 to 400 dollars. Regarding to those who actually had incomes, a $74.7 \%$ did not have any work related to tourism, while a $25.3 \%$ did. About whether they belonged to any type of association or neighborhood group, $72.4 \%$ answered that they belonged and $27.6 \%$ answered that they did not belong. On whether they would like to work in the tourist activity, $66.7 \%$ answered that they would like to, while $33.3 \%$ answered that they would not like it. It is very important to analyze how proud the members of the Commune feel about living in Santay, to which $100 \%$ said they were very proud.

A relation was found between sex and work situation (Pearson Chi-square coefficient $=$ $32,471, p=0.000$ ), between age and time on the island (Pearson Chi-square coefficient $=37,676, p$ $=0.000$ ), between age and work situation (Pearson Chi-square coefficient $=108,907, p=0.000$ ), between age and if you would like to work in tourism (Pearson Chi-square coefficient $=13,937, p=$ 0.007 ), between marital status and time living in the island (Pearson's Chi-square coefficient $=$ $33,153, p=0.000$ ), between marital status and working situation in the island (Pearson Chi-square coefficient $=53,657 ; p=0.000$ ), between marital status and involvement with associations (Pearson Chi-square coefficient $=15,625 ; p=0.001$ ), between marital status and whether if they would like to work in tourism (Pearson Chi-square coefficient $=11,012 ; p=0.012$ ), between the place of birth and time living in the island (Pearson Chi-square coefficient $=35,677, p=0.000$ ), time living in the island and work situation (Pearson's Chi-square coefficient $=74,923 ; p=0.000$ ), between time spent on the Island and income level (Pearson Chi-square coefficient $=28,303, p=0.001$ ), between level of training and work situation (Pearson Chi-square coefficient $=68,244, p=0.000$ ), between the employment situation and work related to tourism (Pearson Chi-square coefficient $=$ $19,576, p=0.012$ ) and between the level of income and work linked to tourism (Chi-square coefficient) of Pearson $=9,047, p=0.029$ ).

\subsection{Positive and negatives aspects derived from tourism development}

In table 5, is shows the positive effects perceived by the community on tourism development, on a five-point Likert scale (1-totally disagree, 5-totally agree) with a series of valued aspects, both economic, sociocultural and environmental. From the results obtained it is observed that all the 
positive aspects are above the 3.20 points, obtaining high scores. The most valued aspects (with scores higher than 4) were "The inhabitants of the island feel more pride for belonging to it" sociocultural aspect with a score of 4.38, "Improvement of access roads to the Island" environmental aspect with a score of 4.37 , "Improvement of the quality of life" sociocultural aspect with a score of 4.15 , "Improves the quality of service in restaurants, shops and cabins in the area" sociocultural aspect with a score of 4.10 and "Contribution to improve the standard of living" economic aspect with a score of $4.08, \mathrm{H}_{3}$.

Table 5. Positive aspects of tourism development

\begin{tabular}{lccc}
\hline Positive aspects & Minimum & Maximum & Mean \\
\hline Economic aspects & & & \\
Improvement of investments, more development and more infrastructures & 1 & 5 & 3.97 \\
Increase in employment opportunities & 1 & 5 & 3.84 \\
Contribution to improve the standard of living & 1 & 5 & 4.08 \\
Tourism is one of the main sources of wealth of the Island's economy & 1 & 5 & 3.94 \\
Tourism contributes to the recovery of traditional crafts & 1 & 5 & 3.75 \\
\hline Sociocultural aspects & 1 & 5 & 4.15 \\
Improvement of the quality of life & 1 & 5 & 3.86 \\
Strengthens the offer of leisure and recreational activities & 1 & 5 & 4,38 \\
The inhabitants of the island feel proud to belong to it & 1 & 5 & 4.10 \\
Improve the quality of service in restaurants, shops and cabins in the area & & & \\
\hline Environmental aspects & 1 & 5 & 3.99 \\
Better protection of the environment & 1 & 5 & 3.20 \\
Improvement of basic infrastructures: water, electricity & 1 & 5 & 4.37 \\
Improvement of access roads to the Island & & &
\end{tabular}

Source: Own elaboration.

Table 6, shows the negative aspects of tourism development. The negative aspects that obtained a higher score belong merely to the group of economic aspects and were "Benefit only for a small number of communards" economic aspect with a score of $3.61, \mathrm{H}_{2}$, followed by "The benefits of tourism activity revert more in companies and people who are not from the Commune" economic aspect with a score of 3.07. The other economic, sociocultural and environmental negative aspects obtained very low scores of less than 3 , so the benefits derived from tourism development (positive aspects) outweigh the costs (negative aspects), $\mathrm{H}_{1}$.

Table 6. Negative aspects of tourism development

\begin{tabular}{lccc}
\hline Negative aspects & Mínimum & Máximum & Mean \\
\hline Economic aspects & 1 & 5 & 2.03 \\
Increase in the price of housing & 1 & 5 & 2.51 \\
Increase in the cost of living & 1 & 5 & 2.54 \\
Increase in the price of products and services & 1 & 5 & 3.61 \\
Benefit only for a small number of communards & 1 & 5 & 3.07 \\
The benefits of tourism activity revert more in companies and people who are & & & \\
not original from the Commune & 1 & 5 & 1.72 \\
\hline Sociocultural aspects & 1 & 5 & 1.74 \\
Increase in robberies, alcoholism, prostitution & 1 & 5 & 2.74 \\
Increased exploitation of the communards & 1 & 5 & 1.64 \\
Changes / loss of traditional culture & 1 & 5 & 2.76 \\
\hline Problems of coexistence between the communards and tourists & \multicolumn{3}{c}{} \\
Loss of tranquility in the area & 1 & 5 & 2.38 \\
\hline Environmental aspects & & & \\
Destruction of the local ecosystem & & & \\
\hline
\end{tabular}

Source: Own elaboration 
Another aspect studied in this research is the relationship between the satisfaction of the communards with the perception of the different positive and negative aspects that are derived from tourism development. Table 7, shows the variables that have the most influence (significant and positive correlation) in the satisfaction of the community members with tourism development are the "Improvement of investments, more development and more infrastructure", "Improvement of quality of life "and" Tourism is one of the main sources of wealth of the Island's economy ". Results similar to (Eshliki \& Kaboudi, 2012). The correlation that exists between the general satisfaction of the community and the development of tourism is mainly related to the positive aspects. However, the variable "Increase of robberies, alcoholism, and prostitution" has a negative correlation with the satisfaction of the community members, so the authorities should make changes to reduce the negative effects produced by this variable.

Table 7. Satisfaction with different positive and negative aspects (Spearman correlation)

\begin{tabular}{|c|c|c|}
\hline Aspects & Correlation & $\begin{array}{c}\text { Group to } \\
\text { which it belongs }\end{array}$ \\
\hline \multicolumn{3}{|l|}{ Positive aspects } \\
\hline Improvement of investments, more development and more infrastructure & $0.439^{* *}$ & Economic \\
\hline Improvement of the quality of life & $0.435^{* *}$ & Sociocultural \\
\hline Tourism is one of the main sources of wealth of the Island's economy & $0.343^{* *}$ & Economic \\
\hline The inhabitants of the island feel proud to belong to it & $0.340^{* *}$ & Sociocultural \\
\hline Increase in employment opportunities & $0.300^{* \pi}$ & Economic \\
\hline Strengthens the offer of leisure and recreational activities & $0.254^{*}$ & Sociocultural \\
\hline Contribution to improve the standard of living & $0.254^{*}$ & Economic \\
\hline Improve the quality of service in restaurants, shops and cabins in the area & $0.257^{\star}$ & Sociocultural \\
\hline Better protection of the environment & $0.251^{*}$ & Environmental \\
\hline Negative aspects & $-0.370^{* *}$ & Socicultural \\
\hline
\end{tabular}

** Significant correlation $1 \%$

* Significant correlation $5 \%$

Source: Own elaboration.

The overall satisfaction of the community with the development of tourism on Santay Island is 4.21 on a Likert scale of 5 points (1- Very dissatisfied, 5 - Very satisfied), $48.3 \%$ of the sample were very satisfied and $36.8 \%$ were they showed satisfied. What shows a high satisfaction of the community in a protected area.

\section{Conclusions}

Conducting research on the perception of the community of tourism development, grants guidelines to build appropriate development plans and programs, ensuring communities its own conservation. The positive aspects most valued by the commune were "The inhabitants of the Island feel more pride for belonging to it" (sociocultural aspect), "Improvement of access roads to the Island" (environmental aspect), "Improvement of quality of life "(sociocultural aspect)," Improves the quality of service in restaurants, shops and cabins in the area "(sociocultural aspect) and" Contribution to improve the standard of living "(economic aspect, similar to Choi \& Sirakaya, 2005; Gursoy et al., 2009).

The negative aspects that obtained a higher score belong only to the group of economic aspects and were "The benefit only for a small number of communards" (Sreekumar \& Parayil, 2002), and "The benefits of the tourist activity revert more in companies and people who are not from the Commune". The other economic, sociocultural and environmental negative aspects obtained very low scores. The benefits derived from tourism development (positive aspects) outnumber and score the costs (negative aspects), so the community is in favour of tourism development. Similar results to (Akis et al., 1996; Yoon et al., 2001; Andereck et al., 2005; Nzama, 
2008; Oviedo-García et al., 2008; Canalejo et al., 2012).

The variables that show a significant and positive correlation in community satisfaction with tourism development are the "Improvement of investments, more development and more infrastructure", "Improvement of the quality of life" and "Tourism is one of the main sources of wealth of the Island's economy ". Results similar to (Eshliki \& Kaboudi, 2012). The correlation that exists between the general satisfaction of the community and the development of tourism is mainly related to the positive aspects. The variable "Increase of robberies, alcoholism, and prostitution "has a negative correlation in the satisfaction of the communards, so the authorities should make changes to reduce the negative effects produced by this variable. The general satisfaction of the communards with the tourism development in Santay Island is 4.21 , which is considered a high satisfaction.

Finally, the main limitation of the present investigation was the failure to find all the inhabitants of the Santay Commune among the visits made to the Island. As a future line of research, it is recommended to carry out a study on the segmentation of the Community in regard to the perception of tourism development.

\section{Acknowledgments}

The authors of the present research work thank the collaboration of the Ministry of Environment of Ecuador for allowing this study to take place in Santay Island.

\section{References}

Akis, S., Peristianis, N., \& Warner, J. (1996). Residents' attitudes to tourism development: the case of Cyprus. Tourism management, 17(7), 481-494.

Almeida-García, F., Peláez-Fernández, M. Á., Balbuena-Vázquez, A., \& Cortés-Macias, R. (2016). Residents' perceptions of tourism development in Benalmádena (Spain). Tourism Management, 54, 259-274.

Andereck, K. L., \& Nyaupane, G. P. (2011). Exploring the nature of tourism and quality of life: perceptions among residents. Journal of Travel Research, 50, 248-260.

Andereck, K. L., Valentine, K. M., Knopf, R. C., \& Vogt, C. A. (2005). Residents' perceptions of community tourism impacts. Annals of tourism research, 32(4), 1056-1076.

Assante, L. M., Wen, H. I., \& Lottig, K. (2012). An empirical assessment of residents' attitudes for sustainable tourism development: a case study of O'ahu, Hawai'i. Journal of Sustainability and Green Business, 1, 1.

Brida, J. G., Osti, L., \& Barquet, A. (2010). Segmenting resident perceptions towards tourism-a cluster analysis with a multinomial logit model of a mountain community. International journal of tourism research, 12(5), 591-602.

Brunt, P., \& Courtney, P. (1999). Host perceptions of sociocultural impacts. Annals of tourism Research, 26(3), 493-515.

Canalejo, A. M., Soto, M. O., \& Guzmán, T. L. (2012). Percepción y actitudes del residente acerca del impacto del turismo en la isla de Santiago (Cabo Verde). Turydes, 5(12).

Cardoso Jiménez, C., Castillo Nechar, M., \& Hernández Vega, C. (2014). Holding tourism or sustainable tourism (TS): theoretical reflections. Estudios y Perspectivas en Turismo, 23(2), 376-395.

Castillo, O. G., \& Gaspar, N. G. (2002). Una década de desarrollo del turismo en Cuba (1990-2000). Editorial Universitaria.

Choi, H. S. C., \& Sirakaya, E. (2005). Measuring residents' attitude toward sustainable tourism: Development of sustainable tourism attitude scale. Journal of Travel Research, 43(4), 380-394.

De Kadt, E. (1979). Social planning for tourism in the developing countries. Annals of Tourism Research, 6(1), 36-48.

Díaz Martínez, J.A. y Martínez Violante (2002) Sociología del Turismo, Editorial UNED, Madrid.

Diaz-Christiansen, S., López-Guzmán, T., \& Pérez-Gálvez, J. C. (2016). Motivations and Valued Attributes of Ecotourism in a Natural Protected Area: Santay Island (Ecuador). Mediterranean Journal of Social Sciences, 7(3), 240.

Diaz-Christiansen, S., López-Guzmán, T., Gálvez, J. C. P., \& Fernández, G. A. M. (2016). Wetland tourism in natural protected areas: Santay Island (Ecuador). Tourism Management Perspectives, 20, 47-54.

Earth Summit. Rio de Janeiro. Brazil (2012)

Easterling, D. S. (2005). The residents' perspective in tourism research: A review and synthesis. Journal of Travel \& Tourism Marketing, 17(4), 45-62. 
Eshliki, S. A., \& Kaboudi, M. (2012). Community perception of tourism impacts and their participation in tourism planning: a case study of Ramsar, Iran. Procedia-Social and Behavioral Sciences, 36, 333-341.

Gee, C. Y., J. C. Mackens, Y D. J. Choy (1989): The Travel Industry. New York NY: Van Nostrand Reinhold.

Gunn, C. (1988), Tourism Planning, Taylor and Francis, London, New York. Routledge.

Gunn, C. A., \& Var, T. (2002). Tourism planning: Basics, concepts, cases. Psychology Press.

Gursoy, D., \& Rutherford, D. G. (2004). Host attitudes toward tourism: An improved structural model. Annals of tourism Research, 31(3), 495-516.

Gursoy, D., Chi, C. G., \& Dyer, P. (2009). Locals' attitudes toward mass and alternative tourism: the case of Sunshine Coast, Australia. Journal of Travel Research.

Gursoy, D., Jurowski, C., \& Uysal, M. (2002). Resident attitudes: a structural

Hall, C. M., \& Page, S. J. (2014). The geography of tourism and recreation: Environment, place and space. Routledge.

Harrill, R. (2004). Residents' attitudes toward tourism development: A literature review with implications for tourism planning. Journal of planning literature, 18(3), 251-266.

Henríquez, C., Zechner, T. C., \& Cioce Sampaio, C. A. (2010). Turismo y sus interacciones en las transformaciones del espacio rural. Rev. austral cienc. soc, (18), 21-31.

Infante Amate, J., Aguilera, E., \& González de Molina, M. (2014). La gran transformación del sector agroalimentario español. Un análisis desde la perspectiva energética (1960-2010).

Kim, K., Uysal, M., \& Sirgy, M. J. (2013). How does tourism in a community impact the quality of life of community residents?. Tourism Management, 36, 527-540.

Ko, D. W., \& Stewart, W. P. (2002). A structural equation model of residents' attitudes for tourism development. Tourism management, 23(5), 521-530.

Kumar Das, D., V.Devadas, Dr., \& Najjamuddinc, Dr. (2003). Integrated Tourism Planning for Sustainable Development. Pakistan Journal of applies sciences, 3 (6), 440-454.

Lankford, S. V., \& Howard, D. R. (1994). Developing a tourism impact attitude scale. Annals of tourism research, 21(1), 121-139.

Látková, P., \& Vogt, C. A. (2012). Residents' attitudes toward existing and future tourism development in rural communities. Journal of Travel Research, 51(1), 50-67.

Lindberg, K., \& Johnson, R. (1997). Modeling resident attitudes toward tourism. Annals of Tourism Research, 24(2), 402-424.

Mahika, E. C. (2011). Current trends in tourist motivation. Cactus Tourism Journal, 2(2), 15-24.

McGehee, N. G., \& Andereck, K. L. (2004). Factors predicting rural residents' support of tourism. Journal of travel research, 43(2), 131-140.

Mclntosh, R. W., \& Goeldner, C. R. (1990). Tourism: Principles, practices, philosophies Wiley. New York.

Minciu, R. (2004). Tourism Economy, III-rd Edition. Uranus Publising House, Bucharest.

Ministry of the Environment of Ecuador (2017).

Ministry of Tourism of Ecuador. MINTUR (2018)

Monterrubio Cordero, J. C. (2008). Residents perception of tourism: a critical theoretical and methodological review. CIENCIA ergo sum, 15(1), 35-44

Murphy, P. (1985). Tourism: a community approach. Methuen: New York and London. Tourism Review, 6(2), 9-10.

Núñez, J., Fuentes, F., \& Sánchez, S. (2015). Actitudes del residente hacia el impacto del desarrollo turístico: estudio empírico. Revista Venezolana de Gerencia, 19(66).

Nzama, A. T. (2008). Socio-Cultural Impacts of Tourism on the Rural Areas Within the World Heritage SitesThe case of KwaZulu-Natal, South Africa. South Asian Journal of Tourism and Heritage, 1(1), 1-8.

Oviedo-Garcia, M., Castellanos-Verdugo, M., \& Martin-Ruiz, D. (2008). Gaining residents' support for tourism and planning. International journal of tourism research, 10(2), 95-109.

Pavlić, I., Portolan, A., \& Puh, B. (2015). The Social Impacts of Tourism on Local Community's Quality of Life.

Petric, L., \& Pivcevic, S. (2016, January). Community based tourism development-insights from Split, Croatia. In Faculty of Tourism and Hospitality Management in Opatija. Biennial International Congress. Tourism \& Hospitality Industry (p. 294). University of Rijeka, Faculty of Tourism \& Hospitality Management.

Rasoolimanesh, S. M., Ringle, C. M., Jaafar, M., \& Ramayah, T. (2017). Urban vs. rural destinations: Residents' perceptions, community participation and support for tourism development. Tourism Management, 60, 147-158.

Regulation for the Registry of Community Tourist Centers. Official Registry 316, Agreement No. 14 - Quito, Ecuador, July 19, 2006.

Ruiz-Ballesteros, E. (2011). Social-ecological resilience and community-based tourism: an approach from Agua Blanca, Ecuador. Tourism Management, 32(3), 655-666.

Sánchez, A. V., Mejía, M. Á. P., \& Bueno, N. P. (2007). Desarrollo del turismo y percepción de la comunidad local: factores determinantes de su actitud hacia un mayor desarrollo turístico. In Empresa global y mercados locales: XXI Congreso Anual AEDEM, Universidad Rey Juan Carlos, Madrid, 6, 7 y 8 de junio de 2007 (p. 24). Escuela Superior de Gestión Comercial y Marketing, ESIC. 
Sampaio, C. A. C. (2005). Turismo como fenômeno humano. Santa Cruz do Sul: EDUNISC.

Santana, A. (1997). Antropología y turismo: ¿nuevas hordas, viejas culturas. Reis. Revista Española de Investigaciones Sociológicas, 223-225.

Schaerer, J., \& Dirven, M. (2001). El turismo rural en Chile. Experiencias de agroturismo en el Maule, la Araucanía y Los Lagos. Publicaciones de las Naciones Unidas, Santiago, Chile.

Sharpley, R. (2014). Host perceptions of tourism: A review of the research. Tourism Management, 42, 37-49.

Sheldon, P. J., \& Abenoja, T. (2001). Resident attitudes in a mature destination: the case of Waikiki. Tourism management, 22(5), 435-443.

Sinclair-Maragh, G., Gursoy, D., \& Vieregge, M. (2015). Residents' perceptions toward tourism development: A factor-cluster approach. Journal of Destination Marketing \& Management, 4(1), 36-45.

Snaith, T., \& Haley, A. (1999). Residents' opinions of tourism development in the historic city of York, England. Tourism management, 20(5), 595-603.

Sreekumar, T. T., \& Parayil, G. (2002). Contentions and contradictions of tourism as development option: the case of Kerala, India. Third World Quarterly, 23(3), 529-548.

Tovar, C., \& Lockwood, M. (2008). Social impacts of tourism: An Australian regional case study. International journal of tourism research, 10(4), 365-378.

World Tourism Organization (2004). Management for tourist saturation in sites of natural and cultural interest: Practical guide, OMT, Madrid, Spain.

Yoon, Y., Gursoy, D., \& Chen, J. S. (2001). Validating a tourism development theory with structural equation modeling. Tourism Management, 22(4), 363-372.

Zhang, J., Inbakaran, R.J., \& Jackson, M. (2006). Understanding community attitudes towards tourism and hostguest interaction in the urban-rural border region. Tourism Geographies, 8(2), 182-204. 